\title{
Hybrid Power Plant with Storage System: University Research Station
}

\author{
Adam Gubański1, Artur Sobkowiak², Michał Jasiński, Dominika Kaczorowska', Przemysław Janik \\ Paweł Kostyła', Zbigniew Leonowicz', Jacek Rezmer ${ }^{1}$, Tomasz Sikorski ${ }^{1}$, Vishnu Suresh ${ }^{1}$

\footnotetext{
1 Department of Electrical Engineering Fundamentals, Faculty of Electrical Engineering, Wrocław University of Science and Technology, 50-370 Wrocław, Wybrzeże Wyspiańskiego 27, Poland
} \\ 2 Wroclaw University of Science and Technology, 50-370 Wrocław, Wybrzeże Wyspiańskiego 27, Poland \\ * Corresponding author, e-mail: michal.jasinski@pwr.edu.pl
}

Received: 24 June 2019, Accepted: 30 September 2019, Published online: 11 October 2019

\begin{abstract}
The article presents a brief overview of renewable energy sources, microgrids and energy storage problems. The construction and utilisation of university research station to study the operation of a hybrid power plant with an energy storage unit has been described. The tested hybrid power plant consists of a photovoltaic panel and a wind turbine. There are two possible areas of research, one is when the microgrid is connected to the main grid and second when it functions independently as a stand-alone setup. In addition, the model allows to study the characteristics of photovoltaic cells, examine the dependence of generated power on the time, season and angle of the solar panel. In this article, the current-voltage characteristics and influence of solar azimuth angle on cell power, dependence of wind on power generated by the wind turbine, and study of off-grid work of power plant are presented.
\end{abstract}

\section{Keywords}

hybrid power plant, microgrid, storage system, photovoltaic, wind power plant, university research station

\section{Introduction}

Photovoltaic (PV) installations and wind installations are renewable energy resources (RES), which can be divided into two basic groups [1]:

- grid-connected,

- off-grid

Grid-connected systems (Fig. 1) are the most common types of RES systems and, according to [2], constitute about $99 \%$ of assembled systems in Poland. In this installation, part of the energy produced is exported to the grid, the meter at the input of the system measures the power consumed from the public grid, and the meter at the output of the system indicates the power that the installation produced. One bidirectional meter can also be used. Appropriate agreements between the owner of the installation and the operator regulate the cooperation between the two entities. In case of cooperation with the network, it is necessary to protect against island system operation. In the event of a failure in the transmission network or inadequate parameters of generated energy, the power plant is disconnected from the system. Off-grid systems

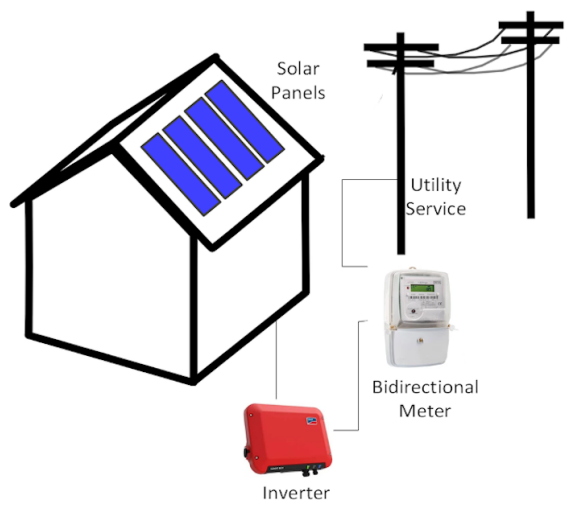

Fig. 1 Grid-connected PV System

(Fig. 2), not connected to the power system, are usually used in places difficult to access, where the construction of the transmission network would be very expensive, or to power devices such as parking meters, traffic lights and signs, meteorological stations and power supply for water pumps [3]. In these types of installations, battery packs are additionally used, which store the generated energy and allow it to be used, for example at night, when energy from photovoltaic panels is not produced. Such systems 


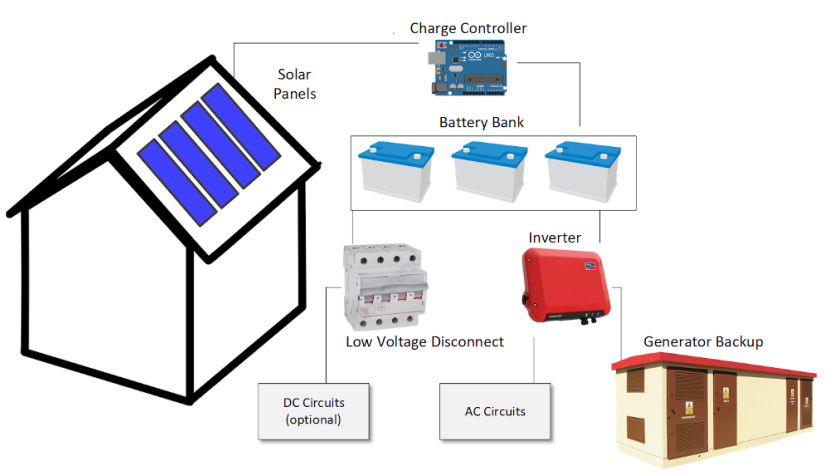

Fig. 2 Off-grid PV System

are often built in combination with other energy sources, such as wind turbines, creating hybrid systems.

On a sunny windless day, energy is produced by means of a solar system, and at night in the absence of solar radiation and favorable wind, energy is supplied via a wind farm. In addition, the installation is equipped with a storage system that allows to use the stored energy even when it is not produced by any RES. According to [4] and [5] a small hybrid installation, with an installed capacity of 3-5 $\mathrm{kW}$, is able to meet the needs of an average polish household.

Electrical energy storage provides a way to store energy in various forms and then it is converted to electricity. Due to the way energy is stored, energy storage can be divided into: mechanical, electrochemical and electrical.

Due to the relatively low prices in relation to capacity, short-term possibility of loading with large currents, simple charging system, high energy density, high power density and long lifetime, the most popular energy storage for cooperation with hybrid power plants are battery storage systems [6].

Important parameters of energy storage devices are their charging and discharging characteristics.

According to [7] most popular hybrid power plants are:

- Wind - Diesel System,

- Wind - Photovoltaic (PV) - Diesel System,

- Wind - Photovoltaic System.

In [8] Wind - Diesel System is discussed. It is shown that the selected hybrid system is only profitable if the wind speed is greater than $11 \mathrm{~m} / \mathrm{s}$ and the fuel price does not exceed $0.9 \$ / \mathrm{L}$.

The paper [9] describes Wind - Photovoltaic - Diesel System with backup energy storage located in Turkey's Sakarya province. It is noted that if the wind speed is low, the optimal hybrid system is a Photovoltaic (PV) - Diesel
-Battery System. In the case of high wind speed, there are two optimal configurations: Wind - Photovoltaic (PV) Battery System, if diesel fuel prices are high. Otherwise the Wind - Diesel - Battery System is more favorable.

Presented university research station shows Wind Photovoltaic System.

Combination of hybrid power plant, storage system, energy demand connected or not to the local power system is called microgrid (Fig. 3) [10, 11].

While there are numerous publications, where sun tracking PV power plants are discussed, i.e. [8], where solar tracker system is designed and executed or [12], where MATLAB simulation is applied to calculate solar angles and location at any time, it is hard to find a real model on which students can see, what actually is happening and how it affects generation. In [13] the real model simulating the Sun's tracks across the sky, as a part of Stanford Solar Center, is presented, but without solar panel or wind turbine. In [14], as a part of a master thesis, a model to determine the best orientation of PV panels according to sun position is discussed, but model is programmed in GIS environment. The lack of a physical model reflecting both the wandering of the sun over the horizon and solar generation caused the need to create a laboratory model at Wroclaw University of Science and Technology.

\section{Research station description}

The research station is a part of the Laboratory located at Wroclaw University of Science and Technology, Faculty of Electrical Engineering, Department of Electrical Engineering Fundamentals. The station is an extension of the laboratory of PV system analysis. The description of on-grid PV research system of the University is described in [15]. In addition PV laboratory consists of:

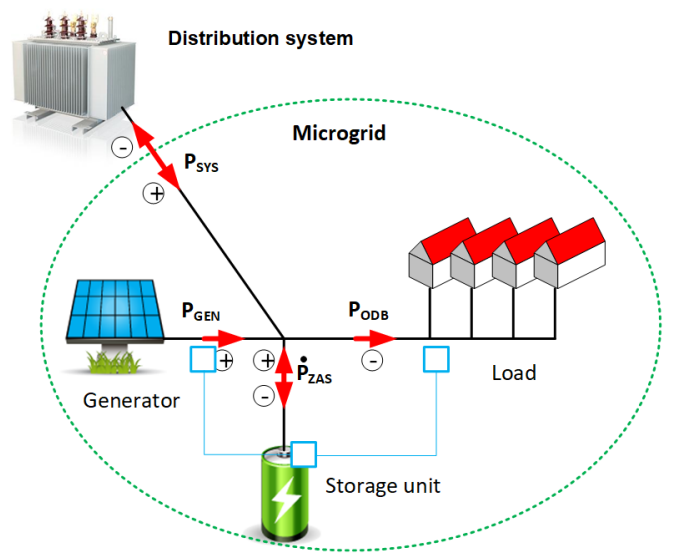

Fig. 3 Scheme of a microgrid [11] 
- monocrystalline and polycrystalline solar panels model, where students can create their own panels by joining solar cells and then measure their V-I and $\mathrm{P}-\mathrm{V}$ characteristics,

- solar cells V-I and P-V characteristics measurement station.

There was a need to analyze the cooperation between wind turbine and solar panels, thus a power plant model was created. The research station was built in fiberboard $60 \mathrm{~cm} \times 100 \mathrm{~cm} \times 2 \mathrm{~cm}$ (width x length x thickness). The view of the station is presented in Fig. 4 and block diagram in Fig. 5.

The research station consist of:

- $500 \mathrm{~W}$ halogen and luminous flux $9500 \mathrm{~lm}$,

- amorphous module with a maximum power of $2 \mathrm{~W}$,

- a single-crystalline silicon cell with a maximum power of about $0.5 \mathrm{~W}$,

- mini wind turbine generating DC voltage in the range of $0-15 \mathrm{~V}$ at rotation $200-6000 \mathrm{rpm}$ with a blower motor from the combustion boiler (Fig. 6),

- $12 \mathrm{~V}$ gel battery with a capacity of $7 \mathrm{Ah}$;

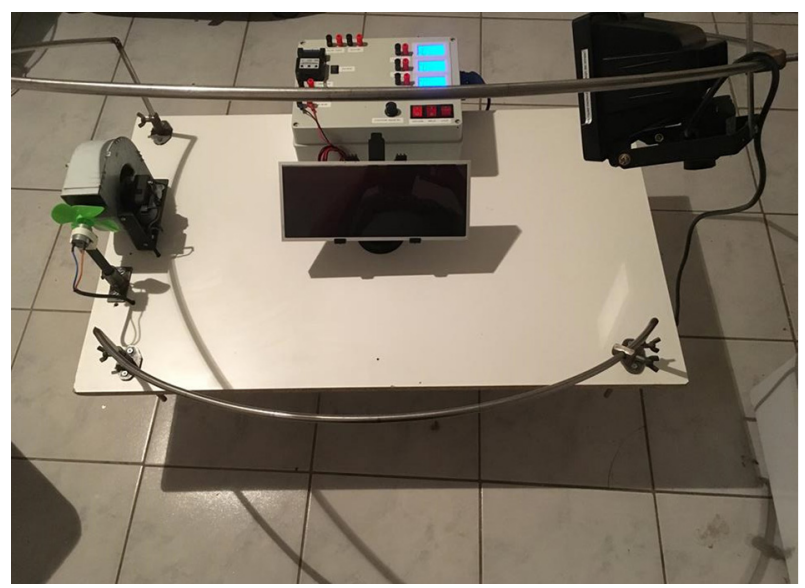

Fig. 4 The view of university research station

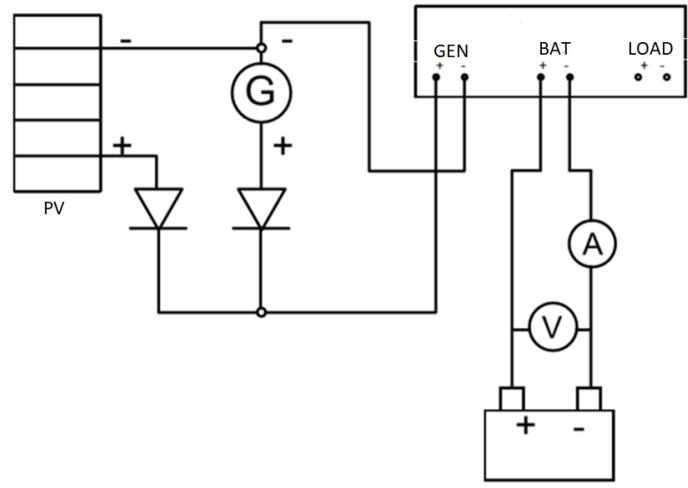

Fig. 5 Block diagram of university research station
- measuring system with a charge regulator, and a regulated load in the form of an adjustable resistor (Fig. 7).

The station was equipped with two pathways, reflecting the apparent movement of the sun during the summer and winter solstice through the sky. The pathways were designed for the latitude of Wrocław, Poland (51 $06^{\circ} 00$ 'N).

The pathways corresponding to the summer solstice, at the point of sun-setting, is inclined to the ground plane at an angle of $62^{\circ}$, the pathway reflecting the winter solstice is at an angle of $16^{\circ}$. The sun is represented by a 500 Watt halogen which, with the help of a handle, can be attached to the "summer" as well as "winter" pathways. The station enables to assemble and examine small cells and photovoltaic modules. The holder of PV modules has the possibility to adjusting the angle $\beta$ in the range of 0 to 90 degrees, and the receiver's azimuth $+/-45^{\circ}$ relative to the meridian.

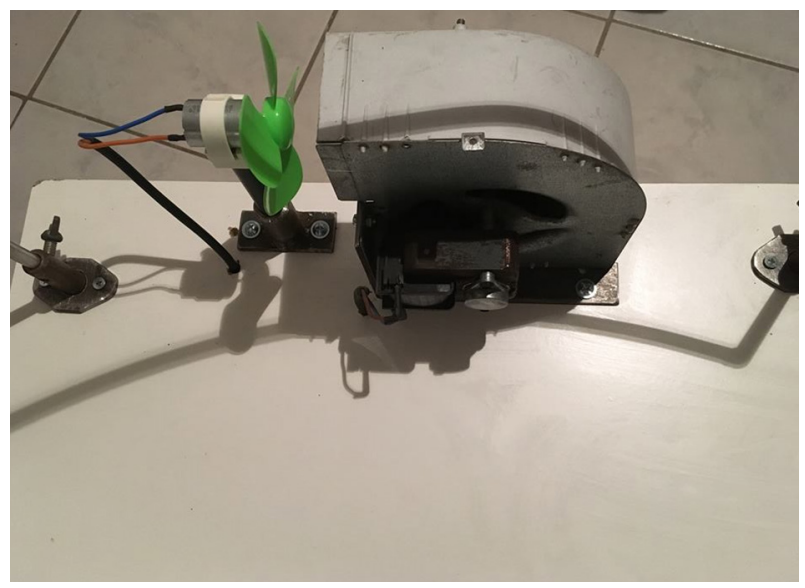

Fig. 6 Mini wind turbine with the inflow providing the source

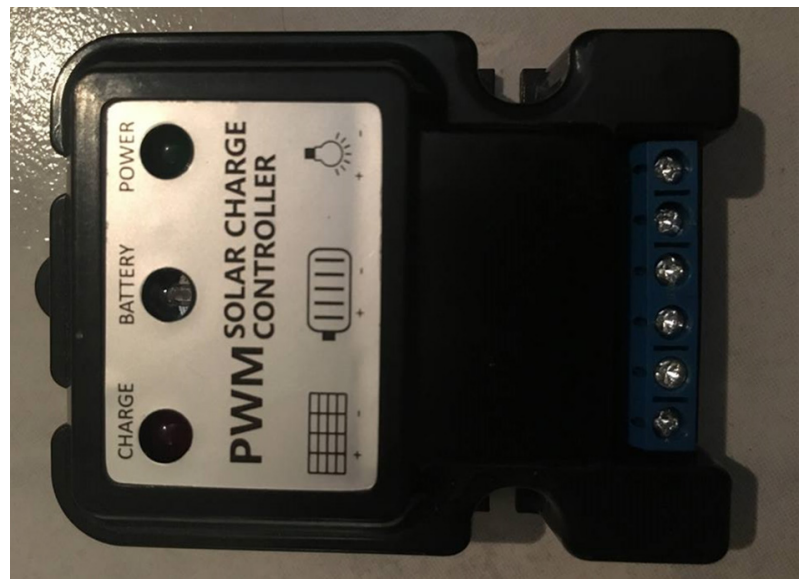

Fig. 7 Charge regulator 
The source of wind for a mini wind turbine is a blower motor from a combustion boiler, which ensures smooth regulation of wind speed in the range from 0 to $10 \mathrm{~m} / \mathrm{s}$.

The function of the energy storage system is fulfilled by a $12 \mathrm{~V}$ gel battery. The capacity of the battery is $7 \mathrm{Ah}$.

\section{Case study}

\subsection{PV research}

The main aim of the PV analysis was to determine the current-voltage characteristics and investigation of solar azimuth angle influence on cell power. The source of light intensity was a $500 \mathrm{~W}$ halogen and a luminous flux of $9500 \mathrm{~lm}$. The investigated objects were monocrystalline silicon cells and an amorphic silicon module. The current-voltage characteristics determination for both cells were conducted in the same conditions. The angle of inclination of solar energy receivers $\beta$ relative to the horizon was $30^{\circ}$. The angle of the sun's falling $\alpha$ s was $62^{\circ}$ - like for Wrocław in summer solstice. The achieved characteristic for amorphic (size: $105 \mathrm{~mm}$ x $55 \mathrm{~mm}$ x $10 \mathrm{~mm}$ ) is presented in Fig. 8 and for monocrystalline (size $120 \mathrm{~mm}$ x $300 \mathrm{~mm}$ x $22 \mathrm{~mm}$ ) in Fig. 9 The analysis of the PV cell parameters are presented in Table 1.

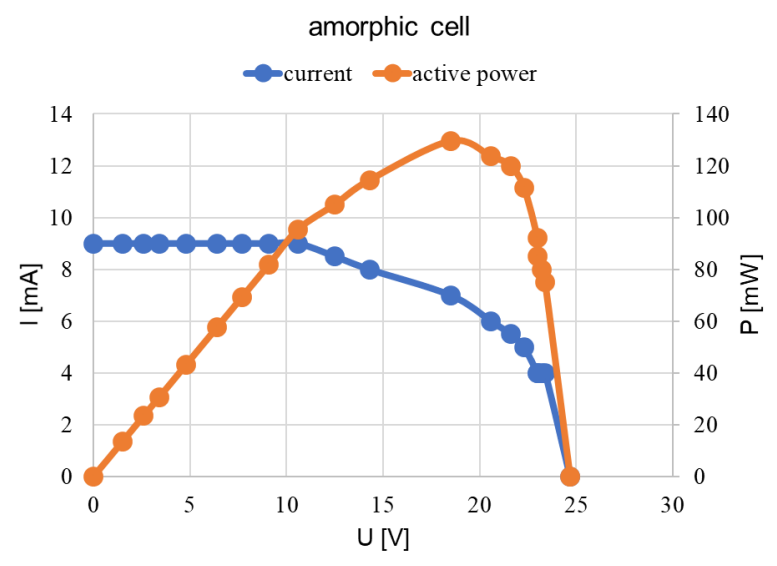

Fig. 8 Characteristic of amorphic cell

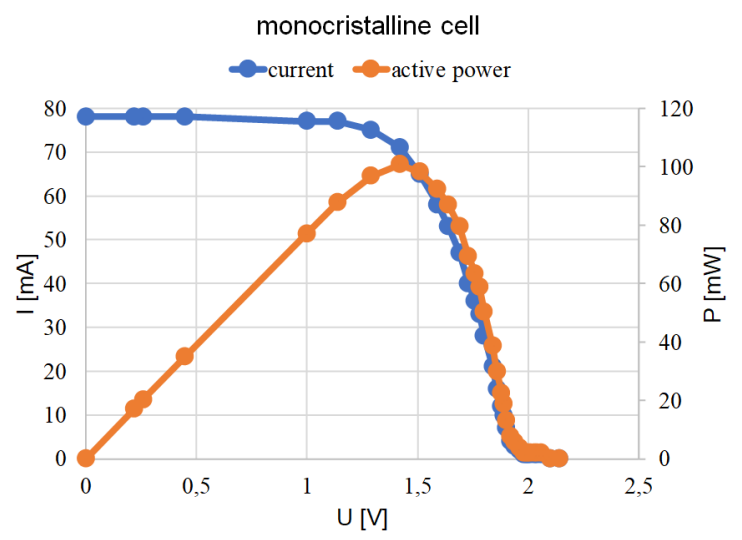

Fig. 9 Characteristic of monocrystalline cell
The next research element was to measure the influence of azimuth of the solar angle on the power of cells. Two tests were conducted for each solar battery for the latitude of Wrocław $\left(51^{\circ} 06^{\prime} 00\right.$ ' $\left.\mathrm{N}\right)$. based on:

- summer solstice,

- winter solstice.

The horizons used were divided in such a way so as to simulate subsequent hours during the day (from sunrise to sunset).

The analysis was conducted for optimal value of resistance of PV cells. The angle of inclination of the tested solar batteries $\beta$ was $45^{\circ}$ in all cases. The azimuth angle of the $\gamma \mathrm{s}$ receivers was $0^{\circ}$.

The results of the analysis presented for amorphic cells are shown in Fig. 10 and for monocrystalline cells (size $120 \mathrm{~mm} \times 300 \mathrm{~mm} \times 22 \mathrm{~mm}$ ) in Fig. 11

\subsection{Wind turbine research}

Wind source was represented as the blowing-in-force from the combustion boiler. The controller is enabled to change the value of the wind speed from 0 to $10 \mathrm{~m} / \mathrm{s}$. The role of the generator was played by a small DC motor. The motor generates a voltage in the range from 0 to $15 \mathrm{~V}$ at a speed of 200-6000 rpm. The voltage and current characteristic of wind turbine is presented in Table 2. The maximal active power (equal to $320 \mathrm{~mW}$ ) was conducted for $9.4 \mathrm{~V}$ which represents the $34 \mathrm{~mA}$ current.

Additionally, the wind turbine curve was determined. The load for the generator was constant, namely equal to the optimal resistance determined in the previous test $(0.27 \mathrm{k} \Omega)$. The wind speed was variable in this case. A voltage regulator connected to the blow motor circuit

Table 1 PV cell parameter analysis

\begin{tabular}{llcc}
\hline parameter & & amorphic & monocrystalline \\
\hline short-circuit current & $I_{s c}$ & $9 \mathrm{~mA}$ & $78 \mathrm{~mA}$ \\
open circuit voltage & $U_{o c}$ & $24.7 \mathrm{~V}$ & $2.1 \mathrm{~V}$ \\
maximum power & $P_{\max }$ & $129 \mathrm{~mW}$ & $101 \mathrm{~mW}$ \\
maximum power & $U_{m p p}$ & $18.5 \mathrm{~V}$ & $1.4 \mathrm{~V}$ \\
point voltage & & $7 \mathrm{~mA}$ & $71 \mathrm{~mA}$ \\
maximum power & $I_{m p p}$ & 0.58 & 0.60 \\
point current & $F F$ & $2642 \Omega$ & 20 \\
fill factor* & & \\
optimal resistance** & $R_{o p t}$ & & \\
$*$ & & & \\
$F F=\frac{P_{\max }}{I_{S C} \cdot U_{O C}}$ & & & \\
$U_{m p p}$ & &
\end{tabular}


Table 2 Wind turbine parameter analysis

\begin{tabular}{llc}
\hline parameter & & wind turbine \\
\hline short-circuit current & $I_{s c}$ & $52 \mathrm{~mA}$ \\
open circuit voltage & $U_{o c}$ & $14.8 \mathrm{~V}$ \\
maximum power & $P_{\max }$ & $320 \mathrm{~mW}$ \\
maximum power point voltage & $U_{m p p}$ & $9.4 \mathrm{~V}$ \\
maximum power point current & $I_{m p p}$ & $34 \mathrm{~mA}$ \\
optimal resistance * & $R_{o p t}$ & $0.27 \mathrm{k} \Omega$ \\
$*$ & & \\
$R_{o p t}=\frac{U_{m p p}}{I_{m p p}}$ & &
\end{tabular}

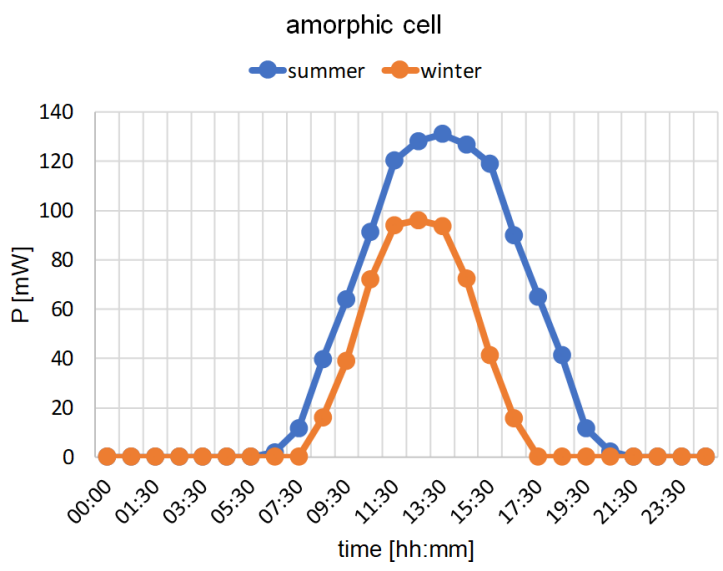

Fig. 10 Characteristic of amorphic cell

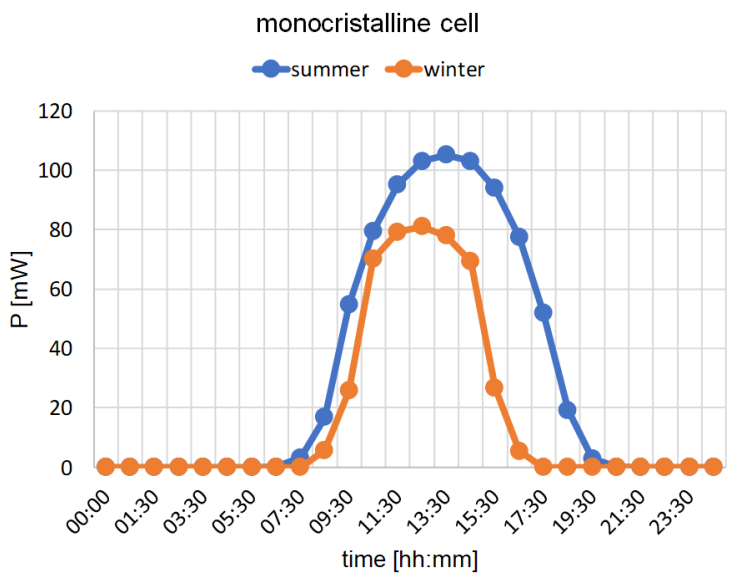

Fig. 11 Characteristic of monocrystalline cell

was used to regulate it. The wind measurement was carried out using a UNI-T UT363 anemometer. The archived characteristic is presented in Fig. 12. Analysis of archived result indicated that start wind speed for the generator is $4.6 \mathrm{~m} / \mathrm{s}$. The maximum power that the turbine obtained at the speed of $10 \mathrm{~m} / \mathrm{s}$ (equal to $320 \mathrm{~mW}$ ). The achieved result is similar to output obtained at determining the current voltage characteristics.

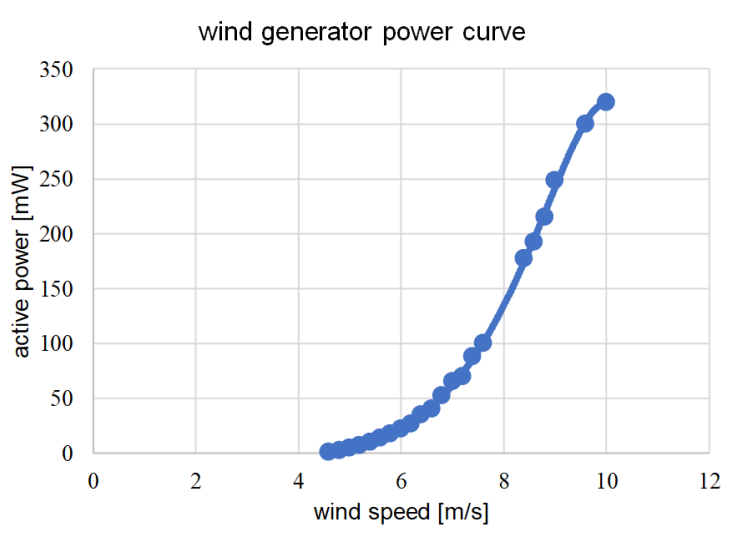

Fig. 12 Wind generator power curve

\subsection{Storage system and islanding working of microgrid}

Both the wind turbine and the solar module are designed to cover the demand (load) and charge the battery that is on the power plant equipment. It is carried out using a charging regulator that controls the current and voltage in such a way as to ensure adequate parameters when charging the battery.

Simulation of the operation of the hybrid power plant took place for the conditions presented in Table 3 .

If the voltage is $12.92 \mathrm{~V}$, the current flowing when charging the battery is $28 \mathrm{~mA}$. Thus, the power that was supplied to the battery is approximately $0.36 \mathrm{~W}$. Assuming that the state of charge of 7 Ah battery would be $50 \%$, it would take 125 hours to recharge it under the above-mentioned conditions using the designed mini power plant.

\section{Conclusions}

Energy obtained from PV - Wind System is unstable, it depends on weather conditions and the season. During sudden weather changes related to the occurrence of atmospheric phenomena, there are changes in the generated power, not allowing to accurately predict the energy that we are able to produce.

The investigations performed using presented example of laboratory of hybrid power plant with storage system

Table 3 Conditions of the operation of the hybrid power plant

\begin{tabular}{llc}
\hline & \multicolumn{2}{c}{ parameter } \\
\hline wind speed & $v$ & $10 \mathrm{~m} / \mathrm{s}$ \\
panel angle & $\beta$ & $45^{\circ}$ \\
panel type & - & amorphic \\
lamp position & - & Summer solstice at noon on sunny day \\
State of Charge & SoC & $50 \%$ \\
battery charging time & $T$ & $125 \mathrm{~h}$ \\
\hline
\end{tabular}


allow to determine characteristics of particular component of the installation including load characteristics, power curves. It has a meaning to define limits and ability of power production of different $\mathrm{PV}$ cell technologies and wind turbines.

\section{References}

[1] Karthikeyan, V., Rajasekar, S., Das, V., Pitchaivijaya, K., Singh, A. "Smart Energy Grid Design for Island Countries", In: Islam, F. M. R., Al Mamun, K., Amanullah, M. T. O. (eds.) Green Energy and Technology, Springer International Publishing, Cham, Schwitzerland, 2017, pp. 125-157.

https://doi.org/10.1007/978-3-319-50197-0

[2] Brewa Efektywna Energia "Fotowoltaika OFF GRID - \#TND 2, Podcast \& Videocast Twój Niezależny Dom" (Off grid photovoltaic - \#TND 2, Podcast \& Videocast Your Independent Home), (in Polish) [online] Available at: https://www.brewa.pl/podcast/ fotowoltaika-off-grid-tnd-2-podcast-videocast-twoj-niezaleznydom.html [Accessed: 27 August 2019]

[3] Alkhalidi, A. A. T., Hussain Al Dulaimi, N. "Design of an OffGrid Solar PV System for a Rural Shelter", PhD Thesis, German Jordanian University, 2018.

https://doi.org/10.13140/RG.2.2.24352.07689

[4] Olasek, W. "Optymalizacja grupy taryfowej i elektrycznej mocy umownej" (Optimization of the tariff group and electric contracted capacity), Olsztyn, 2018. (in Polish) [online] Available at: http:// dotacje-ue.com.pl/wp-content/uploads/2018/07/Optymalizacjataryfy-i-mocy-umownej-18.07.27.pdf [Accessed: 27 August 2019]

[5] CSO, Ministry of Energy "Energy Market Agency, Energy consumption in households in 2015", Warsaw, 2017. [online] Available at: https://stat.gov.pl/download/gfx/portalinformacyjny/pl/ defaultaktualnosci/5485/2/3/1/zuzycie_energii_w_gospodarstwach_domowych_w_2015_r..pdf [Accessed: 27 August 2019]

[6] Waltrich, G. "Energy management of fast-charger systems for electric vehicles: experimental investigation of power flow steering using bidirectional three-phase three-port converters", Technische Universiteit Eindhoven, Eindhoven, Netherlands, 2013. [online] Available at: https://research.tue.nl/files/3660278/752536.pdf [Accessed: 27 August 2019]

[7] Lazarov, V. D., Notton, G., Zarkov, Z., Bochev, I. "Hybrid Power Systems with Renewable Energy Sources - Types, Structures, Trends for Research and Development", In: ELMA 2005, Eleventh International Conference On Electrical Machines, Drives And Power Systems, Sofia, Bulgaria, 2005, pp. 515-520. [online] Available at: https://www.researchgate.net/publication/236012467\%0AHybrid [Accessed: 27 August 2019]
In addition, the efficiency of PV - Wind System is influenced by the appropriate selection of cells as well as the generator, in terms of power and the type of device used.

[8] Phyu, M. Z., Ya, A. Z. "Optimum Design of Wind-Diesel Hybrid System for Remote Area", International Journal of Scientific Enfineering and Technology Research, 3(10), pp. 2445-2452, 2014. [online] Available at: https:/www.researchgate.net/publication/299465501_Optimum_Design_of_Wind-Diesel_Hybrid_ System_for_Remote_Area [Accessed: 27 August 2019]

[9] Uğurlu, A., Gökçöl, C. "A case study of PV-wind-diesel-battery hybrid system", Journal of Energy Systems, 1(4), pp. 138-147, 2017. https://doi.org/10.30521/jes.348335

[10] Kaczorowska, D., Rezmer, J. "Particle swarm algorithm for microgrid optimization", In: 2018 Innovative Materials and Technologies in Electrical Engineering (i-MITEL), Sulęcin, Poland, 2018, pp. 1-4.

https://doi.org/10.1109/IMITEL.2018.8370472

[11] Gubański, A., Kaczorowska, D. "Power flow optimization between microgrid and distribution system", In: 2018 Innovative Materials and Technologies in Electrical Engineering (i-MITEL), Sulęcin, Poland, 2018, pp. 1-4.

https://doi.org/10.1109/IMITEL.2018.8370466

[12] Tudorache, T., Kreindler, L. "Design of a solar tracker system for PV power plants", Acta Polytechnica Hungarica, 7(1), pp. 23-39, 2010.

[13] Scherrer, P., Scherrer, D. "Solstice and Equinox ("Suntrack") Season Model", Stanford University, 2014. [online] Available at: http:// solar-center.stanford.edu/AO/Sun-Track-Model.pdf [Accessed: 27 August 2019]

[14] Gualla, F. "Sun position and PV panels: a model to determine the best orientation", MSc Thesis, Lund University, 2015. [online] Available at: http://lup.lub.lu.se/luur/download?func=downloadFile\&recordOId=7994855\&fileOId=7994856 [Accessed: 27 August 2019]

[15] Jasiński, M., Rezmer, J., Sikorski, T., Szymańda, J. "Integration Monitoring of On-grid Photovoltaic System: Case Study", Periodica Polytechnica Electrical Engineering and Computer Science, 63(2), pp. 99-105, 2019.

https://doi.org/10.3311/PPee.13423 